\title{
FROM CALIPHATE TO MODERN STATE: A Reflection of Ibn Khaldun's Thought
}

\section{Muhammad Zainor Ridho}

State Islamic University Sultan Maulana Hasanuddin Banten

Email: zainor.ridho@uinbanten.ac.id

\begin{abstract}
Ibn Khaldun is one of the great scholars in the fields of sociology, history, philosophy, religion and politics. His thoughts are illuminating to scholars both in the East and the West. This study aims to examine this Muslim scholar's thought on Islamic government and political system. Based on a critical-textual analysis of his work, this study shows that Ibn Khaldun formulates caliphate as general leadership of all Muslims in the world and is aimed at upholding shari'a law and spreading Islamic propagation and functions both for handling religious and worldly political affairs. The philosophical and historical analysis shows that the caliphate emerged upon the death of the Prophet and the ideal system of the caliphate lasted in the four righly-guided of the Prophet's successors. In the subsequent periods, the Islamic leadership theories and practices vary accordingly, ranging from caliphate to imamate. Nowadays, there is a call to return to the caliphate system but, as this study argues, in the Ibn Khaldun practical-realistic theory, such a call is hardly fulfilled due to irreconcilable political system and different socio-religious contexts between those ideal periods and those of the current challenges.
\end{abstract}

Key Words: Ibn Khaldun, Caliphate, Modern State

DOI: https://doi.org/10.20414/ujis.v23i1.345

\section{Introduction}

THIS ARTICLE aims to examine the issue of Islamic political ideology of caliphate (khiläfa) that continues to trigger controversy between the pros and the cons. This idea is constantly sounded by the Indonesian chapter of Hizb Tahrir (Hizbut Tahrir Indonesia/HTI). Such an idea and its controversies are interesting to be examined theoretically and conceptually. Muslim intellectuals and scholars such as al-Ghazali and al-Mawardi have 
discussed the concept of the caliphate in their own work. Other scholars, such as Ibn Khaldun (1332-1406 AD), even goes further by elaborating this concept, especially on the conditions for leadership. ${ }^{1}$ What is needed further is a reexamination of this concept in contemporary time.

In his Prolegomena (Muqaddima), Ibn Khaldun issued five requirements for a caliph. A caliph must be knowledgeable, fair, competent, healthy, and descent of Quraysh tribe. In this respect, Ibn Khaldun tries to contextualize the boundaries of "Quraysh tribe" as one condition for being a caliph. This shows that caliph and caliphate may entail different meaning and concept in views of particular Muslim scholars. Theorization on the caliphate was actually made upon the Prophet Muhammad's death. That is, the caliphate is not a system that must be taken for granted since it developed over a period of time. Differences in the conceptualization of the caliphate, starting from al-Mawardi in his seminal work al-Ahkām al-Sultāniyya to later scholars such as alMawdūdī, Taqiyuddīn al-Nabhani, and 'Abd al-Wahhab Khalaf, just to mention some, ${ }^{2}$ Increasingly show that the caliphate is a matter of contestation, not fixed, unchanged one. ${ }^{3}$

Ibn Khaldun's view of the caliphate as the system of government has reinforced the substance of the government system in the socio-political order of power that developed over time. According to him, there are three types of government systems, namely al-mulk (kingdom), which brings "all people in accordance with the goals and desires of lust". It means instinctual tendencies and desires that are arranged in one individual, such as

${ }^{1}$ See Ann K. S. Lambton, State and Government in Medieval Islam: An Introduction to the Study of Islamic Political Theory: The Jurists (London and New York: Routledge, 1981) and Antony Black, The History of Islamic Political Thought: From the Prophet to the Present, $2^{\text {nd }}$ ed. (Edinburgh: Edinburgh University Press, 2011).

2 See for example Mohammad Hashim Kamali, "Caliphate and Political Jurisprudence in Islam: Historical and Contemporary Perspectives," Muslim World 106, no. 2 (2016): 374-383.

${ }^{3}$ Nadirsyah Hosen, Islam Yes, Khilafah No!, Doktrin dan Sejarah Politik Islam dari Khulafa ar-Rasyidin hingga Umayyah (Yogyakarta: UIN Sunan Kalijaga, 2018), 31. 
egoism and the desire to be arrogant or despotic, trying to realize individual greed based on egoism. And this model of government, according to Ibn Khaldun, must be rejected.

The second is government or political system. It attempts to bring and regulate society or people in accordance with the view of the reason in achieving worldly prosperity and preventing harm. This type of government is praised from one side and denounced on the other. The first type of government resembles what in political science is called authoritarian, individualist, autocratic, or unconstitutional government. In contrast, the second type is referred to as a government (republic) or even a kingdom (constitutional monarchy), which can realize justice to a certain extent.

The third system according to Ibn Khaldun is defined as "synonymous with bringing all people to think in accordance with the path of religion, in fulfilling all their interests, both spiritually and worldly. But the first, the spiritual, must be prioritized. Thus, this third model of government is representative of God as the owner of the Shari'a in safeguarding religion and governing the world with its teachings.

The dialectics of Ibn Khaldun's thought about the concept of caliphate government system with its context that produces such dialectics are interesting to be analyzed. The genesis of Ibn Khaldun's thoughts has influenced social, economic, political and religious life which in turn shaped the development of the scientific world.

There are some studies about Ibn Khaldun and his thoughts. Mohammad Omar Farooq, ${ }^{4}$ From the University of Bahrain, wrote "Islam and Critical Thinking: The Legacy of Ibn Khaldun", and argued for critical thinking as an important part of the human legacy and vital for human beings, as this was pioneered by Ibn Khaldun. Wawan Hernawan offers a comprehensive overview of

\footnotetext{
${ }^{4}$ Mohammad Omar Farooq, "Islam and Critical Thinking: The Legacy of Ibn Khaldun," SSRN (September 1, 2017), https://ssrn.com/abstract=3036700.
} 
Ibn Khaldun's Prolegomena, especially on his idea of history. ${ }^{5}$ Unlike those studies, this present study tries to examine Ibn Khaldun's theory on caliphate and analyze the relevance of it into a modern nation-state.

\section{Ibn Khaldun's Biography}

Waliuddin Abddurrahman bin Muhammad bin Muhammad Ibn Abi Bakar Muhammad bin al-Hasan, Ibn Khaldun's complete name, is one of the great scientists in the field of sociology, history, philosophy, religion and politics. He plays a major role in building and forming social science in the $4^{\text {th }}$ century to the $20^{\text {th }}$ century in influences both the East and West. He was born in Tunis, 1 Ramadan 732/27 May 1332 and died in Cairo, 25 Ramadan 808/19 March 1406. He is known as the founder of Islamic sociology and historian of Islam. His family came from Hadramaut (Yemen), and his genealogy was from a companion of the Prophet, namely Wail bin Hujr. When he was a child, he memorized the Qur'an and studied tajwìd (the reading skill of the Qur'an). He also studied Islamic sciences such as tafsìr (exegesis), hadith (Prophetic Tradition), tawhìd (theology), and figh (law) of the Maliki school of jurisprudence. Moreover, he also studied Arabic linguistics physics and mathematics. ${ }^{6}$

In $751 \mathrm{H}$ (1350), at the age of 21, Ibn Khaldun was appointed as secretary of the Sultan of the Hafs Dynasty, al-Fadl, who was based in Tunisia. But then he quitted his first position because the ruler he supported lost in a battle in $753 \mathrm{AH}$, and he was stranded in Baskarah, a city in Central Maghrib (Algeria). From there he tried to meet with Sultan Abuan Anan, the ruler of Banu Marin in Tilmisan (capital of Central Maghrib) and tried to attract the Sultan's trust.

In $764 \mathrm{H}$, he left for Granada. He was given by Sultan Bani Ahmar the title of ambassador to the country in Castilla (a

${ }^{5}$ Wawan Hernawan, “Ibn Khaldun Thought: A Review of al-Muqaddimah Book," Ushuluddin 23, no. 2 (2015): 173-184, http://ejournal.uinsuska.ac.id/index.php/ushuludin/article/view/1197.

${ }^{6}$ Editorial team, Ensiklopedi Islam, vol. 2 (Jakarta: Ichtiar Baru Van Hoeve, 2002), 158. 
Christian kingdom based in Sevilla) and succeeded brilliantly. However, not long after that, his relationship with the Sultan broke. In $766 \mathrm{AH}$ (1364 AD), he went to Bijayah (Mediterranean coast region in Algeria) at the invitation of the Bani Hafs ruler, Abu Abdillah Muhammad, who later appointed him a prime minister and the same time also served as preacher and teacher. However, a year later Bijayah fell to Sultan Abul Abbas Ahmad, governor of the Qasanthinah (a city in Algeria). For a while, Ibn Khaldun occupied the same position under this ruler, but then he left for Baskarah.

From Baskarah he sent a letter to Abu Hammu, the Sultan of Tilmisan from Bani Abdil Wad. He promised the Sultan support. The Sultan welcomed him and gave him an important position. Ibn Khaldun refused the position because he would continue his self-study, but was willing to campaign to support Abu Hammu. After succeeding, he went to Tilmisan. When Abu Hammu was expelled by Sultan Abdul Aziz (Banu Marin), Ibn Khaldun switched to the side of Abdul Aziz and lived in Baskarah. Arriving at Tilmisan, Ibn Khaldun was still accepted by Abu Hammu, even though he had been guilty of the Tilmisan ruler. He promised himself not to go back into politics. He finally settled in Qal'at of Ibn Salamah and settled there until $780 \mathrm{H}$ (1378 AD) and wrote his monumental book Kitab al-'Ibar wa Diwan al-Mubtada 'wa al-Khabar fi Ayyam al-'Arab wa al-'Ajam wa al-Barbar or al-'Ibar (general history), published in Cairo in 1284. This book, consisting of 7 volumes, contains subjects relating to history, preceded by the Muqaddima (volume 1), which contains a discussion of human social problems.

The Muqaddima paves the way to the discussion of the social sciences. Therefore, in the history of Islam, Ibn Khaldun is seen as the founder of Islamic social and political sciences. According to his opinion, politics cannot be separated from culture, and society is distinguished between urban communities (badawa/city-state) and villages (hadara). While in Egypt, Ibn Khaldun revised and added to the chapter of the Muqaddima regarding sociological 
concepts. ${ }^{7}$ His Muqaddima was a response to the social and political turbulence in the history of Islam, such as the collapse of the Islamic state, fierce political fragmentation and the loss of power.

Ibn Khaldun discussed at length the tension between ideality and reality in Muslim political life and sought to solve the issue by adopting realism that was a feature of modern thought. He subjected the ideal to the reality and the right to the possibility, stating that the dream of Muslims to have a just caliph would not be possible in this imperfect world. That ideal will only be realized if they are supported by sufficient strength. ${ }^{8}$

\section{The Genealogy of the Concept of Islamic Leadership}

The election of Abu Bakr as-Shiddiq marks the first history of the establishment of the caliphate of the Muslim community to replace the Prophet's leadership. This was followed by the third consecutive successor, Umar bin Khattab, Uthman ibn Affan, and Ali bin Abi Talib, who are all later known as the rightly-guided caliphs.

In realizing a new and comprehensive world order, the Prophet Muhammad had reconstructed a part of the Mecca system from the Quraysh into a broader new system of order but still retained the old political and religious orders. With a more practical meaning, the new world order was a form of formulation of the political superstructure in the government system after the death of the Prophet Muhammad as a messenger or head of the government during his leadership period. The messenger death drove a new debate amongst his companions as to who was the most suitable successor. There were some thoughts regarding the model of leadership in the post prophetic era. The debates revolved around two big models; caliphate (khiläfa) and imamate (imāma). Despite similarities and differences between these two concepts, the question that arises is whether they are still relevant. With respect to the main focus of this study, is the caliphate really

${ }^{7}$ Ibn Khaldun, Muqaddimah Ibn Khaldun, trans. Ahmadie Thoha (Jakarta: Pustaka Firdaus, 2000), 207.

${ }^{8}$ Abdelwahab El-Affendi, Masyarakat Tak Bernegara: Kritik Teori Politik Islam, ed. Nuruddin Amin, trans. Amiruddin Ar-Rani (Yogyakarta: LKiS, 2012), 2. 
needed for Muslims, as the proponents claim it so? It is essential, therefore, to trace the birth of the caliphate system.

In The Venture of Islam, Marshall G. S. Hodgson ${ }^{9}$ reveals several important things related to this issue. First, political turmoil in Medina and Mecca. ${ }^{10}$ Beginning with the emergence of a monotheistic prophet when the Prophet Muhammad declared himself as the last messenger. Amongst the people who contended Muhammad's prophethood was Musaylama from the Hanifa clan in Central Arabia, who also declared himself as a prophet. He and his follower accused of the Prophet as being jealous that revelation had to come down to other than himself. Although some of them declared to follow the Prophet, but soon after his death some of them withdrawn such support.

In the next phase, people of Bedouin clan who surrendered to the Prophet Muhammad felt freed from any obligations after waiting for what the Muslims would do in Medina and Mecca because the power of the Quraysh still could not be ignored even though they were separated by the Prophet. In Medina itself, there were consternation and indecision. The Ansar, the Muslims of Medina, immediately proposed that they must elect a leader for the Meccan Muslims. Abu Bakr and Umar were considered to be suitable candidates. Umar pronounced his loyalty to Abu Bakr, and the Ansar immediately followed him as did the Quraysh. The leadership of the Muslims of Medina was the only general mediator that allowed the need for cooperation on a broad scale.

The superiority of Islam as a religion that sustains social order would justify the existence of the Muslim ruler. The caliphate state is no longer just the commonwealth of Arabia but is a means of conquest outside Arabia, while its financial and psychological existence depends in many ways on the conquest. ${ }^{11}$

Prophet Muhammad himself was a revolutionary figure, struggling against the corrupt regime of Quraysh in Mecca, the purpose of which was to build a society that surrendered to God's

9 Marshall G. S. Hodgson, The Venture of Islam: Iman dan Sejarah dalam Peradaban Dunia Masa Klasik Islam, trans. Mulyadhi Kartanegara (Jakarta: Paramadina, 1999), 283-323.

${ }^{10}$ Ibid., 283.

${ }^{11}$ Ibid., 287. 
will and implemented a new form of social justice. The successors of the Prophet continued this tradition, and the revolutionary elements in Islam continued even after Islam became a world power. The first four caliphs after the Prophet developed the example of Islamic leaders who were very important for Muslim history. Abu Bakr, as the first caliph, was chosen by his people after the Prophet died in 632. There was a group of Muslims who believed that the Prophet wanted his son-in-law and deputy, Ali Ibn Abu Talib, as the Imam (Imam) of Islamic communities, but Ali accepted the Abu Bakr caliphate..$^{12}$ Umar replaced Abu Bakar. The third caliph was Ustman, and the forth of the rightly-guided caliph was Ali, whom his supporters called the first imam. ${ }^{13}$

In this context, the birth of the concept of caliphate and imamate originated from the transition of the political leadership from the Prophet to his successors. The harsh debate between the factions of Abu Bakr and Ali upon the death of the Prophet was, in fact, related to the way or mechanism to choose the successor of the messenger. Thus, the fundamental difference between the caliphate and imamate, in essence, lies in the mechanism of the election of a leader in political power upon the Prophet's time.

Second, the conquest of the Sasanid Empire. In 634, Abu Bakar, the first caliph, died, leaving Umar as the most senior and salient figure of the companions who fit to succeed Abu Bakar. In the following years, Islamic expansion continued to the surrounding areas of what is now known as Saudi Arabia Peninsula. The other power was the Sasanid Empire which also made conquest in the region. After Muslims succeeded in conquering this empire, they were also able to conquer adjacent lands outside this imperial boundary. It was the political reasons that led to the conquest of the Sasanid empire, specifically the ongoing crises within the empire that brought about its fall. But these political reasons were expressions of cultural reasons that were more lasting for the lot unity of the Irano-Semitic cultural regions between the Nile and the Oxus, and their differences from

${ }^{12}$ Karen Amstrong, Perang Suci: Dari Perang Salib Hingga Perang Teluk, trans. Hikmat Darmawan (Jakarta: Serambi Ilmu Semesta, 2004), 508.

${ }^{13}$ Hodgson, The Venture of Islam, 288. 
the purer Greek regions of the peninsula. Only in Maghrib and Spain did the Arabs conquer far areas without referring to the Sasanid power base.

Third, the conquest organization of Umar. ${ }^{14}$ The main problem in the Prophet Muhammad's time was to replace a system of feuds (feuding) in a society, by siding with a general life under an arbitrator. Under Umar, the same problem was renewed in new conditions and situations to enforce some general disciplines among residents who were less concerned with the laws of the conquered territories. The problem for Umar, and also for the people of Medina he represented, was how to define the nature of that authority at the centre of such a government.

Abu Bakr was known as the representative of the Prophet Muhammad, his caliph. This is basically an emergency status. The term caliphate continued to be used by Umar, but he replaced it with Amir al-Mu'minin (commander of the believers). The only binding authority that the Arabs must acknowledge was the authority of military commanders in marching to new grazing places or during wars. Therefore, the only legitimate position was the position of military commander (warlord) even though with limited authority. This position as commander rests on personal prestige, namely prestige in religion. Because the actions of any group that transcends tribal interests is a problem for religion, we can say that it is precisely in religious matters that it is the successor of "caliph" to the Prophet. ${ }^{15}$

Therefore, the position of Umar, whether religious or military, was based on personal relations, as well as those within the ummah, even among powerful Arabs, organizations that were directly personal. In reality, it is an institution capable of operating far from the direct intervention of a particular individual. This organization is centred on a military diwan, namely a register (register) of all Muslims in Medina and Mecca and soldiers who conquer their deeds. This system recognizes that conquests are the main problem (keynote) for Muslim countries, and helps

\footnotetext{
${ }^{14}$ Ibid., 297.

${ }^{15}$ Muhammad Dhiauddin Rais, Teori Politik Islam, ed. Euis Erinawati, trans. Abdul Hayyie al-Kattani (Jakarta: Gema Insani Press, 2001), 120.
} 
perpetuate this situation. With the distribution of the spoils as the most attractive physical source for the state, then carrying out conquests was clearly very favoured. Even so, Umar also gave freedom to the conquered territory to maintain the ownership of the people who were conquered. Furthermore, Umar emphasized Islam as the basis of Arab life. The Prophet has left many open questions in the developing life of Medina. At least according to later Muslim tradition, Umar tightened family law, emphasizing the principle of harsh punishment for criminals.

Thus, the entire Arab community is sorted according to strict Muslim criteria. The state was centred in Medina and was founded on the basis of the Prophet Muhammad's religious prestige, but he also included all the Arab ruling classes as integral members scattered throughout the conquered provinces. The spirit of the New Order was symbolized in that era adopted by Umar, a period beginning with the hijra (migration) of the Prophet Muhammad when he severed ties with the tribal and went to Medina to form a new order. The term hijra itself can also be applied to the migration of individuals or a tribe to the cities of the new military camp, namely in joining the active Muslim community, each individual repeats for himself an essential step which has orbited the Muslim community as a whole.

Fourth, the first and second slander events. ${ }^{16}$ This event is a continuation of the history of the birth of a Caliphate country which began during the leadership of the Prophet to the four guided caliph, namely Abu Bakr, Umar, Uthman and Ali. Uthman had continued the policies of Umar but with less ability. Under the rule of Uthman had emerged what was called the "Umayyad Caliphate" (because all of his effective representatives, starting from Uthman, were from the Umayyad family). ${ }^{17}$

Uthman could not, as Umar did, detained the wealthiest families of Mecca to go to the provinces, especially Iraq, and make business adventures there, disturbing the less fortunate local Arabs. This also reduces the threat to an earthy unified culture of

\footnotetext{
${ }^{16}$ Ibid., 305.

17 Tawfiq Muhammad al-Shawi, Syura Bukan Demokrasi, ed. Subhan, trans. Djamaluddin Z.S. (Jakarta: Gema Insani Press, 1992), 221.
} 
culture into the fertile culture of the Thabite Moon region and strengthens the central power physically. But this did not make Uthman popular among the Meccans.

Many people began to complain about Uthman's tendency to nepotism. They see their family's clicks as the cause of many of their other complaints. Although he himself was one of the first converts to Islam, Uthman came from the Umayyad family, most of them, like their leader Abu Sufyan, had opposed Muhammad until the last minute. Umar has used the extensive experience and abilities of the family members, man Uthman almost gave them and their colleagues a monopoly from the highest offices, often allowing themselves to be controlled by them. This has made it unpopular among the Ansar Madinah family. There are several indications that Ali b. Abi Talib had begun to oppose the policies of Umar and, moreover, opposed the wisdom of Uthman. He is known as a brave soldier and has been felt as a mouthpiece for people who are not satisfied. Now he has become a symbol of a protesting group.

The situation was out of control, and the unsatisfied people were able to kill the caliph of Uthman. The rebels and most of the people of Medina raised Ali in acclamation as the new caliph, who accepted it after a brief delay. 'A'isha, the Prophet's wife, along with two companions who were very prominent among the Meccan companion, then called for revenge for the death of' Uthman and attacked Ali for not punishing the rebels as murderers. ${ }^{18}$ Ali had not received recognition in Syria and Mu'awiya b. Abi Sufyan, as the governor there, in turn, demanded revenge for Utsman. Many of the Prophet's leading friends were "neutral", refusing to take sides in disputes among Muslims.

The second slander occurred in the Mu'awiyah government as one of the embryos of the birth of the Caliphate state. The Mu'awiyah (661-680) restored unity to the ruling Arab community. Basically, he has restored the system which has been Umar created and under the authority of Uthman not adapted to the ongoing political tradition, even though $\mathrm{Mu}^{\prime}$ awiya was not too dependent

18 Sayed Khatab and Gary D. Bouma, Democracy in Islam (New York: Routledge, 2007), 45. 
on the Umayyad family as the main supporter of his policy. Arabs, who were aware of their precarious position in the provinces which were conquered and tormented by the horror of dissidence in Islam, most of them were quite happy to accept a plan that would end their mutual competition on the basis of quite generous agreement, even though it was a party, namely the party of the Syrians was more profitable. It is this power that helps the belief of most Muslims to view him as the person most likely to be able to impose unity among Muslims and thereby give him their loyalty as Islamic leaders. ${ }^{19}$

\section{Caliphate and Imamate: In Search of Concept}

In the modern history of Islamic political discourse, caliphate as a theory and concept began to be discussed again by a Muslim philosopher, namely 'Ali Abd Raziq, who had previously been coined by Ibn Khaldun (1332-1395).

In general, theories about imāma or khilāfa are classified into three. First, the theory that views imamate and the formation of the state as obligations and pillars of religion, as this is advanced by Shi'i. According to them, an imam may be selected by people, but the process of appointment must be based on religious texts. Second, the theory that views that imamate and the state is not an obligation, nor a prohibition on religion. It is not a religious duty but a social matter involving human relations. And the third is the middle theory that positions itself between the two theories above. This theory states that imamate is mandatory but must be based on the electoral process, not on the basis of religious texts. ${ }^{20}$

The caliphate is a governmental, institutional system in Islam. It is an Islamic government that is not limited by territories, so the Islamic caliphate encompasses various tribes and nations worldwide. The bond that unites the caliphate is Islam as religion. In essence, the caliphate is a general leadership that deals with religion and statehood as a representative of the Prophet.

\section{${ }^{19}$ Ibid., 224.}

${ }^{20}$ See Ali Abd Raziq, "Kaum Muslim dan Penafsiran-Penafsiran Modern," in Pembaruan Islam: Dari Mana dan Hendak Ke Mana, ed. Jean Couteau, by Abdou Filali-Ansary, trans. Machasin (Jakarta: Mizan, 2009), 127. 
According to Ibn Khaldun, ${ }^{21}$ Caliphate is the general leadership of all Muslims in the world to uphold the laws of Islamic shari'a and bear the propagation of Islam throughout the world. It is a general responsibility that is in accordance with the goals of Islamic law which aims to realize the world's and the hereafter's welfare. In essence, a caliphate is a substitute for the function of the shari'a maker, namely God and His Prophet, in the matter of religion and world political affairs. ${ }^{22}$ Therefore, the caliphate is the replacement of the Lawmakers by the caliph, as a religious enforcer and as the regulator of world affairs in terms of religion. ${ }^{23}$ There are two main issues regarding caliphate. The first is concerned with the procedure for appointing caliph as a substitute for the Prophet in leading Muslims, while neither the Qur'an nor the Prophetic tradition explained this procedure. The second is the authority and power that is attributed to the successors of the Prophet. ${ }^{24}$

Furthermore, Ibn Khaldun said that caliphate is also synonym to imamate, which points to overall leadership relating to religious affairs and world affairs in lieu of the function of the Prophet Muhammad. The function of the Prophet Muhammad as a prophet cannot be replaced, while his function as a community leader was continued by the caliphs who were guided (al-Khulafä ${ }^{\prime}$ al-Rashidūn). To replace the function of prophethood (al-nubuwwa) imamate was formed which aims to preserve religion and regulate (siyāsa) the world. Proponents of imamate claim that it is a matter of state. There are differences of opinion between the Sunni and Shi'i as to whether imamate is a human political contract or a divinely ordained and chosen system?

First, the Sunnis argue that imamate is a worldly issue whose matters and other related technicalities are up to Muslim communities to formulate. The nomination of a leader is carried out by the special committee or representative. According to alMawardi, the appointment of leader was carried out deliberately by the Ahl al-Iktiyār (those who have the authority to elect leader),

21 Abdul Aziz, Chiefdom Madinah: Salah Paham Negara Islam (Jakarta: Pustaka Alvabet, 2011), 16.

\footnotetext{
${ }^{22}$ Rais, Teori Politik, 154.

${ }^{23}$ Editorial team, Ensiklopedi Islam, 2:50.

${ }^{24}$ Ibn Khaldun, Muqaddimah Ibn Khaldun, 234.
} 
who were considered capable of selecting an imam. The member of this electing committee or group must be fair, knowledgeable, and wise. These qualities will allow them to select the best candidate. Meanwhile, a candidate of imam or leader must be fair and just to all the conditions relating to it. A candidate must also be knowledgeable in terms of religion and social welfare. Furthermore, a candidate must be physically healthy and sufficient insight to improve social affairs. A candidate must also have courage and strength to protect territory and people and to expel enemies. The last condition is that a candidate must hold Quraish clam origin. ${ }^{25}$

In contrast to the Sunni view, the Shi'i, especially the Imamiya sect, argued that imamate was a central issue and part of the ruling of faith. According to them, the issue of imamate does not include the public interest which is left to the opinion of the Muslim community (ummah), but it is the pillar of religion and the basis of Islam which is determined by Allah through the text. The position of head of government is not the right of every person, but the right of 'Alī bin Abī Țâlib and his descendants. The Imamiya Shi'i goes on to argue that the fifth imam is Muhammad al-Baqīr, and the sixth is Ja'far al-Șadiq. However, members of this sect disagreed with determining the seventh imam. Some argue that the seventh is Ismā'îl bin Ja'far, the first son of Imam Ja'far. This group was later known as Isma'ili Shi'i. ${ }^{26}$

To some, the caliphate is, in fact, a rather obscure concept. There is a wide debate amongst Muslim scholar about the caliphate. In principle, Ibnu Khaldun distinguishes three levels or types of political regimes: first, the caliphate, the direct religious regime, in accordance with the correct Islamic model; second, a monarchy based on brute strength or blind despotism and, between them, a monarchy that uses force, but works within the framework of Shari'a. ${ }^{27}$ Ibn Khaldun concluded with three types that the first type is difficult to realize; the second cannot be

\footnotetext{
${ }^{25}$ Ibid., 51.

${ }^{26}$ Editorial team, Ensiklopedi Islam, 2:205.

${ }^{27}$ Ibn Khaldun, Muqaddimah Ibn Khaldun, 238.
} 
permitted according to reason; while the third is the most realistic and can be taken during the transition period.

Muhammad Imarah, a contemporary Muslim scholar, ${ }^{28}$ contends the caliphate is part of the sacred Islamic reference and therefore should not be questioned. Meanwhile, Ali Abd al-Raziq emphasized the fact that the main transition was a transition that separated the Prophet's era from the next era, not a well-guided caliphate, which had a profound impact on the formation of Muslim religious awareness. In other words, only the leadership of the Prophet and four companions that followed which is considered as a valid caliphate. ${ }^{29}$ Al-Mawardi, who accepted the system of government in the name of Islam, only described the predominant state of his time with terms derived from religion. ${ }^{30}$

\section{The Dialectics of Islamic State and Modern State}

At the end of the 19th century, Muslim thinkers began to examine the caliphate or sultanate state critically. The relationship between politics as a profane entity and Islam as a sacred entity has long been the focus of scholarly debate. This was stimulated by the intention of Muslim countries to adopt the caliphate or an Islamic state. According to Bassam Tibbi, the impetus was the identity crisis suffered by the Islamic community, and secondly, the socio-economic crisis and its impact on poverty.

According to Mohammed Arkoun, ${ }^{31}$ The relationship between Islam and politics can be assessed through two approaches. First, a conventional historical approach that produces a descriptive explanation. Second, the approach to thought and reflection about the problems and difficulties that have arisen concerning the Islamic and political arena, beginning from the experience of

28 Abdou Filali-Ansary, "Pembaruan Islam: Dari Mana dan Hendak ke Mana?," in Pembaruan Islam: Dari Mana dan Hendak ke Mana?, ed. Jean Couteau, trans. Machasin (Jakarta: Mizan, 2009), 123.

${ }^{29}$ Ibid., 125.

30 Mohammed Abed al-Jabiri, "Reformasi Agama dan Pembaruan Pengetahuan," in Pembaruan Islam: Dari Mana dan Hendak Ke Mana, ed. Jean Couteau, by Abdou Filali-Ansary, trans. Machasin (Jakarta: Mizan, 2009), 151.

31 Abdullah Saeed, Islamic Thought: An Introduction (London: Routledge, 2006), 117. 
Muhammad's prophetic mission in Mecca and continuing until his political experience in Medina. Arkoun then asked "how is the relationship between religion and politics in the Qur'an and the Sunnah of the Prophet? The answer first comes states that the relationship between Islam and politics can be realized into a state/government entity and must be based on the Qur'an and Sunna as two authoritative sources. The second view suggests that such a relationship does not necessitate a model of Islamic government.

Fazlur Rahman argued that to carry out a total reconstruction of the understanding of Islam, it must be distinguished between normative and historical Islam. Normative Islam is the basic values and divine norms contained in the Qur'an which are clarified by the Sunnah of the Prophet. As for Islam, history is Islam that is translated by Muslims in a historical context.

Therefore, what is called Islamic politics certainly refers to politics by using Islamic normative values. However, it is still important to distinguish between Islam and Islamic politics. Islam (in the ideal sense), is a doctrine that cannot be doubted while Islamic politics is more subjective, because it is the result of a person's interpretation or thought or Muslim society experience. This is an embodiment of historical Islam. Islam is the word of Allah and the Sunnah of the Prophet, while Islamic politics is the result of interpretation (ijtihad) of normative Islam. What happened with the caliphate system upon the time of the Prophet is part of historical Islam and Islamic politics. ${ }^{32}$ Whereas according to Munawir Sjadzali, ${ }^{33} \mathrm{~A}$ former Indonesian diplomat and Minister of Religious Affairs, Islam only has a set of ethical values, but not a system, including the political system, because the system is everchanging. He further argues that it is therefore very difficult to determine a single system of Islamic state and politics.

The forerunner to the birth of the modern idea of Islamic state began in the first half of the $20^{\text {th }}$ century after many Muslim-

32 See Johan Hendrik Meuleman, Tradisi, Kemodernan dan Metamodernisme: Memperbincangkan Pemikiran Mohammed Arkoun (Yogyakarta: LKiS, 1996), 133.

33 Dhororudin Mashad, Akar Konflik Politik Islam di Indonesia (Jakarta: Pustaka Al-Kautsar, 2008), 7. 
populated regions in Asia and Africa were free from European occupation and proclaimed independent state. Some of the newly born nation-states declared themselves as Islamic states and adopted Islam as the basis of the state.

Ibn Khaldun, as one of the medieval Muslim thinkers, proposed theory or concept of the state in the context of the caliphate. ${ }^{34}$ The approach used by Ibn Khaldun in developing theories about the state was also normative and doctrinal. This can be seen from his opinion about imamate and the function of an imam, a view which is similar to the opinion of al-Mawardi. In his perception, al-Mawardi emphasizes the importance of imamate, the position of the caliph as an imam, and the duties and functions of the imam. Although both have commonalities, they also show a different view.

Ibn Khaldun saw the relationship between Islam and the formation of the state on the basis of sociological generalizations that tended to be holistic with normative ideological generalizations. In sociological-ideological terms, așabiyya (ethnocommunal bond) is a binder that ties social groups together and bears political authority. Political authority is needed to make human affairs organized and must be borne by the most powerful individuals or groups in society. Formal or state political authority (mulk) is different from informal leadership (riyasa) in realizing coercion at a higher level. Religion and morality can cause either damage or even strengthen așabiyya. The state remains the main determinant of the fate of political power. Ibn Khaldun denied the classic argument of Muslim theologians and philosophers who saw religion as the basis of social order and statehood. The state, naturally, grows out of social order because without a central authority and unrivalled authority, society will be destroyed by an incessant war. The most primitive and most basic form of state is natural power (mulk tabi'i) based on brutal power. At a higher level is political power or rational (mulk siyāsi) power based on a rational search to meet public needs.

Meanwhile, Ibn Khaldun paid attention to the form of power that developed in classical to modern times. Power, according to

\footnotetext{
${ }^{34}$ Ibid., 29.
} 
him, consists of two types, namely the ruler who pays major attention to efforts to maintain power and only works in the public interest as long as it benefits the ruler. Second is the ruler who is solely concerned with the general welfare.

These three perceptions on the relation of the state and religion. The first perspective argues that the state must officially be an "Islamic state" which is subject to the Islamic Shari'a as the law of Allah and that the Islamic state must be realized by the Muslim community which prioritizes the Qur'an and Sunna. For supporters of the Islamic State, the government of the Prophet Muhammad in Medina was historically political evidence that the "State of Medina" was truly a unit of political government that was built on community agreements. This group believes that "the State of Medina" is a real form and an example of an Islamic State in the early days. This belief is based on arguments, namely: first, the Messenger of Allah received allegiance from various groups of people as rulers who governed the lives of different ethnic and religious groups. As a result, the Prophet was appointed as the leader of the country; and second, the law of this state is binding and compelling, where the Prophet always based it on revelation and the laws of Allah ${ }^{35}$.

The second perspective believes in the goodness of a secular state that separates state and religious affairs. The concept of a secular state sees that state affairs are not a religious matter, and therefore the authority of the state should be separated from religious interference, and vice versa. In other words, separation of religion and the state is compulsory, as the proponents of secularism contend.

Meanwhile, the third view considers the state and religion as two sides of the same coin. This combines Islamic interests and values in the practice of the state without necessarily becoming an Islamic state. This attempts to media between those two opposing views; religious vis a vis secular state. This view maintains that the state and religion (Islam) are basically a unit which is inseparable from one another. However, it is important to note that Islam is

\footnotetext{
${ }^{35}$ Ibid., 120.
} 
not an institution formalized as a form of state, but more than that, Islam becomes the spirit of value in carrying out the life of the nation and state. ${ }^{36}$

The concept of an "Islamic State" (Dawla Islämiya) is not supported by truly new theoretical developments, but on the contrary, by the failure of the nation-state which was established after independence. The concept of an Islamic state paradoxically strengthens the state institution that is strongly opposed. In fact, it ends with deification from the country it takes over in form or structure. To reinforce the historical evidence for the birth of an Islamic state, the supporters point to the example of Khilaffah alRashida government which became the reference of Muslims. To its supporters, the idea of khiläfa, although it was empirically liquidated by Mustafa Kamal Atatturk and was theoretically attacked by Ali Abd Raziq, has been replaced by the concept of an Islamic state. In addition, the characteristics of the Islamic state include main characters, such as the sovereignty of God and the superiority of shari'a as the law.

In al-Maududi's view, the structure of Islamic government consists of three components, namely the executive body called Uli al-Amr or Amir, legislative body called Ahl al-Hall wa al-'Aqd and a judicial body called al-Qad̄a. Amir is the highest leader, who must carry out government duties as well as religious duties (priests) because, in this view, there is no such separation between the state and religion in Islam. An amir is chosen by all Muslims in the country for an unlimited tenure except if he breaks the law of God and can only be passed down through a referendum. An Islamic government is defined as a government whose officials are Muslims who carry out Islamic obligations and do not commit disobedience openly, and their constitution comes from the Qur'an and Sunnah, namely applying Islamic shari'a.

This comparative view suggests that there is no agreement amongst the Muslim scholars on the concept of political Islam and Islamic leadership. What needs to be understood in this context is the rediscovery of Islam as a basis for social values, as a basis for solidarity and basic ethics without which Muslim communities are

${ }^{36}$ El-Affendi, Masyarakat Tak Bernegara, 9. 
not realized. So, how to rebuild the political concept itself should not be forgotten that the state must rely on values that are recognized and adopted by society. For the proponents of an Islamic state, this problem is still present and cannot be solved only by reason and historical reasons. If the religious state must be eliminated, and indeed, in reality, it has been removed by history, there is no contradiction with an approach that aims to work on the basis of ethics from politics through religion. ${ }^{37}$ It other words, it is religious values and ethics which are universal and adaptable, not a system, that must lighten politics.

According to David Held, ${ }^{38}$ The modern country is developing as a cosmopolitan country. The conception of the modern state according to Held include control of the means of violence, impersonal power structures and legitimacy. Only when claims of "divine rights" and "state rights" are opposed and deposed will it be possible for humanity as "individuals" and "as people" to win the place as "active citizens" in the political record.

Some characteristics of modern government include the priority of the people as the highest authority in a state administration. The position is the mandate of the people - not the leader. A leader becomes a "servant" of the people and is accountable for the people they lead. Power must be shared, and the people may take part in it. Leaders will organize an open and objective system of government. Furthermore, the government must be accountable and responsive and run the principle of check and balance process. Finally, the stability of the country for the realization of a just and prosperous society is mandatory.

\section{Conclusion}

There are still debates about this system in modern time. The supporters of the caliphate maintain that a state must be based on religion and that caliphate best represent that model. The birth of an Islamic state originates from this paradigm. This view, in fact, is imagining or glorifying the past into the present. To them,

\footnotetext{
${ }^{37}$ Aziz, Chiefdom Madinah, viii.

38 al-Jabiri, “Reformasi Agama,” 149.
} 
religion is the only world of meaning known up to that time and considered as a universal value that cannot be denied. Islamic state in this perspective covers several characters. These include that sovereignty is in the hands of God. The highest law is shari'a, and the government is the holder of God's mandate to carry out His will. The government must not exceed the limits of authority as determined by God. ${ }^{39}$

However, when we look carefully the history, it is revealed that the ideal shape of the Islamic state developed in the time of the Prophet's successors, namely Abu Bakr, Umar, Uthman and Ali. Their reign can be said to be manifestations of the characteristics of the modern government.

The idea of the caliphate that is proposed by Ibn Khaldun, which has been compared to the thoughts of other Muslim scholars as well as a theorist of the modern state, suggests that this Muslim scholar see caliphate as an ideal type of Islamic government system. Dues to its idealism, the caliphate works best in the period of the four-guided-caliph upon the Prophet Muhammad times, which we can claim as representing elements of modern government.

\section{References}

Amstrong, Karen. Perang Suci: Dari Perang Salib Hingga Perang Teluk. Translated by Hikmat Darmawan. Jakarta: Serambi Ilmu Semesta, 2004.

Aziz, Abdul. Chiefdom Madinah: Salah Paham Negara Islam. Jakarta: Pustaka Alvabet, 2011.

Black, Antony. The History of Islamic Political Thought: From the Prophet to the Present. 2nd ed. Edinburgh: Edinburgh University Press, 2011.

Editorial team. Ensiklopedi Islam. Vol. 2. 8 vols. Jakarta: Ichtiar Baru Van Hoeve, 2002.

39 See Burhān Ghalioun, “Kasus Dunia Arab: Benturan Beberapa Revolusi,” in Pembaruan Islam: Dari Mana dan Hendak Ke Mana, ed. Jean Couteau, by Abdou Filali-Ansary, trans. Machasin (Jakarta: Mizan, 2009), 143. 
El-Affendi, Abdelwahab. Masyarakat Tak Bernegara: Kritik Teori Politik Islam. Edited by Nuruddin Amin. Translated by Amiruddin Ar-Rani. Yogyakarta: LKiS, 2012.

Farooq, Mohammad Omar. "Islam and Critical Thinking: The Legacy of Ibn Khaldun." SSRN (September 1, 2017). https://ssrn.com/abstract=3036700.

Filali-Ansary, Abdou. "Pembaruan Islam: Dari Mana dan Hendak ke Mana?" In Pembaruan Islam: Dari Mana dan Hendak ke Mana?, edited by Jean Couteau, translated by Machasin. Jakarta: Mizan, 2009.

Ghalioun, Burhān. "Kasus Dunia Arab: Benturan Beberapa Revolusi." In Pembaruan Islam: Dari Mana dan Hendak Ke Mana, edited by Jean Couteau, by Abdou Filali-Ansary, translated by Machasin, 140-144. Jakarta: Mizan, 2009.

Hernawan, Wawan. "Ibn Khaldun Thought: A Review of alMuqaddimah Book." Ushuluddin 23, no. 2 (2015): 173-184. http://ejournal.uinsuska.ac.id/index.php/ushuludin/article/view/1197.

Hodgson, Marshall G. S. The Venture of Islam: Iman dan Sejarah dalam Peradaban Dunia Masa Klasik Islam. Translated by Mulyadhi Kartanegara. Jakarta: Paramadina, 1999.

Hosen, Nadirsyah. Islam Yes, Khilāfah No!, Doktrin dan Sejarah Politik Islam dari Khulafa ar-Rasyidin hingga Umayyah. Yogyakarta: UIN Sunan Kalijaga, 2018.

Ibn Khaldun. Muqaddimah Ibn Khaldun. Translated by Ahmadie Thoha. Jakarta: Pustaka Firdaus, 2000.

al-Jabiri, Mohammed Abed. "Reformasi Agama dan Pembaruan Pengetahuan." In Pembaruan Islam: Dari Mana dan Hendak Ke Mana, edited by Jean Couteau, by Abdou Filali-Ansary, translated by Machasin, 146-167. Jakarta: Mizan, 2009.

Kamali, Mohammad Hashim. "Caliphate and Political Jurisprudence in Islam: Historical and Contemporary Perspectives." Muslim World 106, no. 2 (2016): 374-383.

Khatab, Sayed, and Gary D. Bouma. Democracy in Islam. New York: Routledge, 2007. 
Lambton, Ann K. S. State and Government in Medieval Islam: An Introduction to the Study of Islamic Political Theory: The Jurists. London and New York: Routledge, 1981.

Mashad, Dhororudin. Akar Konflik Politik Islam di Indonesia. Jakarta: Pustaka Al-Kautsar, 2008.

Meuleman, Johan Hendrik. Tradisi, Kemodernan dan Metamodernisme: Memperbincangkan Pemikiran Mohammed Arkoun. Yogyakarta: LKiS, 1996.

Rais, Muhammad Dhiauddin. Teori Politik Islam. Edited by Euis Erinawati. Translated by Abdul Hayyie al-Kattani. Jakarta: Gema Insani Press, 2001.

Raziq, Ali Abd. "Kaum Muslim dan Penafsiran-Penafsiran Modern." In Pembaruan Islam: Dari Mana dan Hendak Ke Mana, edited by Jean Couteau, by Abdou Filali-Ansary, translated by Machasin. Jakarta: Mizan, 2009.

Saeed, Abdullah. Islamic Thought: An Introduction. London: Routledge, 2006.

al-Shawi, Tawfiq Muhammad. Syura Bukan Demokras. Edited by Subhan. Translated by Djamaluddin Z.S. Jakarta: Gema Insani Press, 1992. 